\title{
Socio - Economic Psychological Profile of Redgram (Cajanus cajan L. Mill sp.) Growers and Perceived Constraints and Suggestions for Application of Production Technologies
}

\author{
Mohd. Riyaz ${ }^{1}$, D. Raghupathi ${ }^{2 *}$ and M. Venkatesh ${ }^{3}$ \\ ${ }^{1}$ Department of Agricultural Extension, GKVK, University of Agricultural Sciences \\ Bangalore, India \\ ${ }^{2}$ UASB, Zonal Agricultural Research Station VC Farm, Mandya, Karnataka, India \\ ${ }^{3} U A S B$, College of Agriculture, VC Farm Mandya, Karnataka, India \\ *Corresponding author
}

\section{A B S T R A C T}

\begin{tabular}{|l|}
\hline K e y w o r d s \\
Socio, economic \\
and psychological \\
profile, Redgram \\
technologies, Farm \\
university \\
technologies, \\
Application of \\
technologies, \\
Market price, \\
Labour scarcity. \\
\hline Article Info \\
\hline $\begin{array}{l}\text { Accepted: } \\
\text { 12 February } 2020 \\
\text { Available Online: } \\
\text { 10 March } 2020\end{array}$ \\
\hline
\end{tabular}

\section{Ke y w o r ds}

Socio, economic and psychologica teflie, Redgram university technologies, Application of Market price Labour scarcity.

12 February 2020

\section{Introduction}

The Redgram crop (Cajanus cajan L. Millsp.) is a protein rich pulse food, consumed in the form of split dal. In Karnataka State of Indian union, it was being grown in an area of 7.70L. ha area with production of $3.50 \mathrm{Mt}$. with
The research study was conducted in Bidar district of Karnataka with the objectives of finding the socio, economic and psychological profile of Redgram growers and the constraints they faced in application of recommended technologies of farm universities to increase the productivity to meet the increasing demand for pluses in India. The study found that the Redgram growers had low social, psychological and economic profile, which inhibited them to apply the recommended technologies of farm universities to the full extent. The extent of application of production technologies was 60.20 percent. The remaining technologies were either partially applied or not applied. The perceived constraints of the growers were many among them, the most severe one was less remunerative price as the market price was highly fluctuating and coupled with, the support price announced by the Government was meager and was not procuring all the quantity grain, secondly there was high labour wages and their scarcity to undertake the timely production operations, likewise the three other constraints were ranked. There is need to address the constraints with appropriate technical, behavioral and policy interventions by the developmental agencies. 
Indians are vegetarians and on an average they consume 70 to 80 grams of pulses per day. There is a potential scope to increase the productivity from 7.60 to 15.0 and more $\mathrm{q} / \mathrm{ha}$ provided the farmers apply the recommended technology of farm universities. In the process of application, the farmers undergo socio, economic and psychological constraints, which required to be studied. Since it is dry land crop requires its own adaphic and climatic conditions for increased productivity with quality grains, The North-East Karnataka region, the Kalaburgi and Bidar districts are called as "Pulse bowl of Karnataka". Large number of farmers are cultivating in wider spread area. Keeping these in view, the study was conducted during 2017-18 in Bidar district of Karnataka during 2017-18.

Statement of the problem; the reviews revealed that the farmers' socio economic level was low and many of them were living below the poverty line in Northern Karnataka state, where the large area and production of Redgram is coming up. The farmers were getting low grain yield per unit area and not fetching the remunerative price in the market and earning marginal profits.

There is potential scope to double the grain yield productivity provided essential extension and support services are extended timely to them, further, to increase the production of the crop the social, economic and psychological orientations to purchase the inputs of production and managing the crop play key role in the production process.

With this backdrop, the research questions set were ; what extent they had, social, economic and psychological attributes for application of recommend technologies released by the farm Universities?. And what were their perceived constraints to apply the technologies and their feedback suggestions to improve the technology performance, based on their farming experiences? These need to be investigated to find answers, this would help in developing an strategic action plan and to frame policies to increase the grain yield productivity and profits to the farmers.

The objectives of the study were, to delineate the socio, economic and psychological attributes of Redgram growers and to list the perceived constraints and suggestions in application of recommended technologies.

\section{Materials and Methods}

The study was conducted in Bidar district of Karnataka State, which consists of five taluks, from these three taluks namely Aurad, Bhalki and Basavakalyan were selected by considering the large area under Redgram cultivation. The sample size was 120 . The respondents were selected by random sampling procedure.

The Research design adopted was Ex-post facto research, exploratory type was used (Kerlinger, 1973).

The Socio, economic and psychological variables for the study were; Education, Land holding, Farming experience, Incentives received from Govt., Social participation, Innovative proneness, scientific orientation and Income level of respondents. These were measured by adopting the procedure suggested by the authors, with slight modifications wherever necessary.

Each independent variable was measured as per the procedure outlined by the authors. The procedure was assigning nominal score to the items listed under each variable on a three point continuum of "agree, dis-agree and neutral" and also seeking dichotomous responses for the questions asked. A nominal score ' 2 ' for Yes and ' 1 ' for No, were awarded and measured. 


\begin{tabular}{|c|c|c|}
\hline Sl. No. & Variables & Empirical measurement \\
\hline \multicolumn{3}{|c|}{ A. Social } \\
\hline 1. & Education & Procedure followed by Shashidhara (2003). \\
\hline 2 & Land holding & $\begin{array}{l}\text { Procedure followed by Maraddi (2006) with slight } \\
\text { modifications. }\end{array}$ \\
\hline 3 & Farming experience & Procedure followed by Binkadkatti (2008) \\
\hline 4. & $\begin{array}{l}\text { Incentives received from } \\
\text { Govt. }\end{array}$ & $\begin{array}{l}\text { Consisted of close and open end type with Face } \\
\text { validity content items. }\end{array}$ \\
\hline 5 & Social participation & $\begin{array}{l}\text { Scale developed by Saravanakumar (1996) with slight } \\
\text { modifications. }\end{array}$ \\
\hline \multicolumn{3}{|c|}{ B. Psychological } \\
\hline 6 & Innovative proneness & Scale developed by Feaster (1968). \\
\hline 7 & Scientific orientation & $\begin{array}{l}\text { Scale developed by Supe (1969) with slight } \\
\text { modifications. }\end{array}$ \\
\hline \multicolumn{3}{|c|}{ C. Economic } \\
\hline 8 & Income level & Procedure followed by Prakash (2000). \\
\hline
\end{tabular}

The score obtained by the respondents, against the maximum score possible was calculated and hierarchically categorized as high, medium and low. In some variables actual information expressed by the respondents was recorded (Education and Income level). An Alternate hypothesis was set; there would be low socio, economic and psychological level of attributes of respondents for full application of production technologies .

The data were collected and analysed by developing interview schedule and data collection considering the objectives of the study a structured interview schedule was prepared by seeking advice of experts and was pre-tested in non-sample area and modifications were incorporated. An apparent of content validity of all the items was ensured before the interview schedule was finalised. The data were collected from the selected respondents visiting the villages of the Bidar district during 2017-18. The interview schedule was administered to the respondents and oral information and opinion expressed by oral and from memory was documented. The visual observations were made accordingly. While collecting information care was taken to avoid onlookers' influence and group pressure on the respondent to ensure pertinent information. The Participatory Rural Appraisal tools such as Focus Group Discussions and Transact walk were also used to supplement the data wherever required. The secondary sources reports and records were referred from the developmental departments. The Statistical tools and tests used for data analysis were frequency, percentage, mean, standard deviation were used.

\section{Results and Discussion}

\section{The respondent's social profile}

\section{Education level}

Nearly quarter per cent of respondents were illiterates and followed by one fourth of them had high school level of education remaining small percent of them were distributed from primary up to graduation level (Table-1). It is to infer that, the illiterates did not utilize the print media (leaflets, folders, newspapers, 
magazines etc.) for application of production technologies available in the farm universities.

\section{Land holding}

Majority of the respondents (54\%) had medium size land holding s ranging from 5 to 10 acres of dry land (Table-1). There was ample scope to apply the production technologies including farm mechanization.

\section{Farming experience}

The table-1 reveals that many of the respondents $(47.0 \%)$ had long farming experience even more than 30 years (Table1). The longer experience more the exposure to modern technologies much access to the farm university technologies can be expected change in their traditional farming.

Extent of benefits received: The respondents had availed benefits such as crop insurance, free inputs and subsidized implements, seeds, fertilizers, plant protection chemicals, etc, from the Department of Agriculture, Govt. of Karnataka through its gross feeder institute Raitha Samparka Kendras. Majority of the respondents $(55 \%)$ had availed to the extent of Rs. 1000 to 5000 during 2016-17 (Table1). This implies that the farmers had applied recommended technologies to some extent as provided inputs were subjected to recommendations of the farm universities. Social participation: Majority of the respondents $(54 \%)$ had medium level of social participation. The respondents had participated in local institutions either as a member or office bearer in the institutes such as farmers association, commodity associations, grama panchayats, SHGs, cooperatives etc. When they participate in the institutions they expose to the different programs, technologies related to Redgram production run by government and NGOs.
Especially the extension programs organized by farm Universities and the Karnataka State Department of Agriculture which will enable them to apply the production technologies for increased production.

\section{Psychological variables}

This include, innovative proneness and Scientific orientation. The overall level was low. This implies that the respondents believed in traditional superstitions, traditions, and customs and lacked innovativeness, scientific orientation and lead to less management orientation of the crop. Further this inhibits them to invest and to lean and apply the new farm innovations. Scientific orientation: The data in Table-1 reveals that, majority of the Redgram growers had medium scientific orientation whereas, one third of them and few of them had low and high level of scientific orientation respectively.

\section{Economic: income level}

It includes farm power, material possession, type of house and annual income level. The overall farm economic level was low. Majority of them were living below poverty line (Table-3). This should and had been hindering factor in procurement of inputs and application of recommended technologies. The overall social, psychological and economic was profile was low.

Perceived constraints as perceived by the respondents expressed for gaps in application of technologies

The table-5 reveals about the constraints in application of production technologies, these constraints have been ranked. The market price fluctuation is severe constraint and low support price from the Government, followed by high wages and timely non-availability of 
labour to undertake the timely production operations to double the yield and income of the growers. Likewise eight other constraints have been ranked.

\section{Technical constraints}

Non-availability of timely expertise advisory services and less competency of field extension personnel to advise the growers. Less competent in diagnosis facilities, on the spot solution providers Wondangbeni (2010) and Rajashekhar (2009). Perceived Suggestions by the respondents: Supply of good quality of inputs at right time through Government institution and private agencies. Construction of warehouse facilities created nearby, storage facility helps them to store and hold the produce during market glut and enable the farmers to fetch better price. Provide water conservation technologies those are helpful during uncertainty and uneven distribution of rainfall. Providing timely technical guidance, regarding recommended seed rate, seed treatment and application of pesticides \& fertilizer by the experts. Establishment of rural markets at nearby places.

Table.1 Social profile of Redgram growers ( $n=120)$

\begin{tabular}{|c|c|c|c|c|c|c|}
\hline Sl. No & Characteristics & Category & Frequency & $\%$ & Mean & SD \\
\hline \multicolumn{7}{|c|}{ Social } \\
\hline \multirow{8}{*}{1} & \multirow{8}{*}{ Education } & Illiterate & 27 & 22.50 & \multirow{8}{*}{2.04} & \multirow{8}{*}{1.76} \\
\hline & & Primary school & 13 & 11.00 & & \\
\hline & & Middle school & 21 & 17.50 & & \\
\hline & & High school & 24 & 20.00 & & \\
\hline & & Diploma/ ITI & 15 & 12.00 & & \\
\hline & & Pre university & 13 & 11.00 & & \\
\hline & & Graduate & 7 & 6.00 & & \\
\hline & & Total & 120 & 100.00 & & \\
\hline \multirow{5}{*}{2} & \multirow{5}{*}{$\begin{array}{l}\text { Land holding } \\
\text { (acres) }\end{array}$} & Marginal farmers & 10 & 8.00 & \multirow{5}{*}{8.18} & \multirow{5}{*}{4.84} \\
\hline & & Small farmers & 40 & 33.00 & & \\
\hline & & Medium farmers & 65 & 55.00 & & \\
\hline & & Big farmers & 5 & 4.00 & & \\
\hline & & Total & 120 & 100.00 & & \\
\hline \multirow{4}{*}{3} & \multirow{4}{*}{$\begin{array}{l}\text { Farming } \\
\text { experience (years) }\end{array}$} & Less $(<2)$ & 25 & 21.00 & \multirow{4}{*}{9.54} & \multirow{4}{*}{12.82} \\
\hline & & Moderate ( 3 to 10 years) & 39 & 32.00 & & \\
\hline & & Long (>10 years) & 56 & 47.00 & & \\
\hline & & Total & 120 & 100.00 & & \\
\hline \multirow{6}{*}{4} & \multirow{6}{*}{$\begin{array}{l}\text { Extent of benefits } \\
\text { received } \\
\text { (Rs./anum) }\end{array}$} & $<1000$ Rs. & 30 & 25.00 & \multirow{6}{*}{1.39} & \multirow{6}{*}{0.85} \\
\hline & & 1000-5000 Rs. & 40 & 33.00 & & \\
\hline & & 5000-10000 Rs. & 10 & 8.00 & & \\
\hline & & >10000 Rs. & 5 & 4.00 & & \\
\hline & & Not received & 35 & 29.00 & & \\
\hline & & Total & 120 & 100.00 & & \\
\hline \multirow{4}{*}{5} & \multirow{4}{*}{ Social participation } & Low & 34 & 28.50 & \multirow{4}{*}{0.86} & \multirow{4}{*}{0.66} \\
\hline & & Medium & 65 & 54.00 & & \\
\hline & & High & 21 & 17.50 & & \\
\hline & & Total & 120 & 100.00 & & \\
\hline
\end{tabular}


Table.2 Psychological profile of Redgram growers $(n=120)$

\begin{tabular}{|c|c|c|c|c|c|c|}
\hline Sl. No & Characteristics & Category & Frequency & $\%$ & Mean & SD \\
\hline \multicolumn{7}{|c|}{ Social } \\
\hline \multirow{4}{*}{6} & \multirow{4}{*}{$\begin{array}{l}\text { Innovative } \\
\text { proneness }\end{array}$} & Low & 27 & 23.00 & \multirow{4}{*}{19.6} & \multirow{4}{*}{1.67} \\
\hline & & Medium & 53 & 44.00 & & \\
\hline & & High & 40 & 33.00 & & \\
\hline & & Total & 120 & 100.00 & & \\
\hline \multirow{9}{*}{7} & \multirow{9}{*}{$\begin{array}{l}\text { Scientific } \\
\text { orientation }\end{array}$} & Low & 39 & 32.00 & \multirow{9}{*}{9.33} & \multirow{9}{*}{1.86} \\
\hline & & Medium & 62 & 52.00 & & \\
\hline & & High & 19 & 16.00 & & \\
\hline & & Total & 120 & 100.00 & & \\
\hline & & 1000-5000 Rs. & 40 & 33.00 & & \\
\hline & & 5000-10000 Rs. & 10 & 8.00 & & \\
\hline & & $>10000$ Rs. & 5 & 4.00 & & \\
\hline & & Not received & 35 & 29.00 & & \\
\hline & & Total & 120 & 100.00 & & \\
\hline
\end{tabular}

Table. 3 Income level profile of Redgram growers $(n=120)$

\begin{tabular}{|c|c|c|c|c|c|}
\hline Sl. No & Indicators & Components & Frequency & $\%$ & Level \\
\hline \multirow{6}{*}{1} & \multirow{6}{*}{ Farm power } & Wooden plough & 63 & 52.50 & \multirow{6}{*}{ Low } \\
\hline & & Iron plough & 65 & 54.00 & \\
\hline & & Seed drill & 45 & 37.50 & \\
\hline & & Tiller & 08 & 7.00 & \\
\hline & & Sprayer & 60 & 50.00 & \\
\hline & & Tractor & 12 & 10.00 & \\
\hline \multirow{6}{*}{2} & \multirow{6}{*}{$\begin{array}{c}\text { Material } \\
\text { possession }\end{array}$} & Radio & 25 & 21.00 & \multirow{6}{*}{ Low } \\
\hline & & Television & 104 & 87.00 & \\
\hline & & Cycle & 78 & 65.00 & \\
\hline & & Pump set & 30 & 25.00 & \\
\hline & & Two wheeler & 48 & 40.00 & \\
\hline & & Four wheeler & 06 & 5.00 & \\
\hline \multirow{4}{*}{3} & \multirow{4}{*}{ House type } & Mud walled thatched & 57 & 47.50 & \multirow{4}{*}{$\begin{array}{c}\text { Less } \\
\text { furnished }\end{array}$} \\
\hline & & Brick walled tiled & 47 & 39.00 & \\
\hline & & Concrete house & 10 & 8.00 & \\
\hline & & Concrete double storied & 06 & 5.00 & \\
\hline \multirow{3}{*}{4} & \multirow[t]{3}{*}{$\begin{array}{l}\text { Annual income } \\
\text { (Rs.) }\end{array}$} & $\begin{array}{c}\text { Below poverty line } \\
(2.50 \text { lakhs })\end{array}$ & 104 & 87.00 & \multirow[t]{3}{*}{ Low } \\
\hline & & $\begin{array}{l}\text { Above poverty line } \\
\text { (2.50 to } 6.0 \text { lakhs) }\end{array}$ & 14 & 11.50 & \\
\hline & & Creamy layer (>10.0 lakhs) & 02 & 1.50 & \\
\hline
\end{tabular}

Mean $=11.04 ; \mathrm{SD}=3.93$; Inference: The overall income level was low 
With this, low overall social, psychological and economic profile, all the respondents had applied the recommended technologies to the extent of 66.20 percent and remaining either partial and not applied (Table-4 and Fig 2). To provide high grain yielding and pest resistance varieties of pod borer and wilt disease resistance varieties. Provide timely credit from cooperative societies and nationalized banks to purchase the inputs and resource management.

Table.4 Technology Practice-wise application gaps in Redgram cultivation $(n=120)$

\begin{tabular}{|c|c|c|c|c|}
\hline SI.No & Cultivation Practices & $\begin{array}{l}\text { Full } \\
\text { application } \\
(\%)\end{array}$ & $\begin{array}{l}\text { Partial } \\
\text { application } \\
(\%)\end{array}$ & $\begin{array}{l}\text { No } \\
\text { application } \\
(\%)\end{array}$ \\
\hline 1 & $\begin{array}{l}\text { Preparatory tillage (Deep ploughing and } \\
\text { pulverising the soil) }\end{array}$ & $\begin{array}{c}120 \\
(100.00)\end{array}$ & 0.00 & 0.00 \\
\hline 2 & $\begin{array}{c}\text { Recommended varieties (Hyd-3C, TTB-7, ICP- } \\
\text { 7035, BRG-1,2,4,5. }\end{array}$ & $102(85.00)$ & 0.00 & $18(15.00)$ \\
\hline 3 & Sowing time & $96(80.00)$ & 0.00 & $24(20.00)$ \\
\hline 4 & $\begin{array}{l}\text { FYM/Compost application (3tons/ha with } \\
\text { Trichoderma). }\end{array}$ & $38(32.00)$ & $50(42.00)$ & $32(26.00)$ \\
\hline 5 & Seed rate $(15 \mathrm{kgs} / \mathrm{ha})$ & $43(36.00)$ & $77(64.00)^{*}$ & 0.00 \\
\hline 6 & $\begin{array}{l}\text { Seed treatment (Sodium molybdate with melted } \\
\text { jiggery solution \& biofertilisers, Rhizobium and } \\
\text { PSB). }\end{array}$ & $43(30.00)$ & 0.00 & $77(70.00)$ \\
\hline 7 & Spacing $(60 \times 20 \mathrm{~cm})$ & $28(23.00)$ & 0.00 & $92(77.00)$ \\
\hline 8 & Transplanting (Dibbling) & $22(18.00)$ & 0.00 & $98(82.00)$ \\
\hline 9 & Use of Fertilizers (25-50-25kg NPK/ha) & 0.00 & $115(96.00)$ & $5(4.00)$ \\
\hline 10 & $\begin{array}{l}\text { Irrigation (protective irrigation twice flower and } \\
\text { pod stages) }\end{array}$ & $28(23.00)$ & 0.00 & $92(77.00)$ \\
\hline 11 & Nipping operation & $30(25.00)$ & 0.00 & $90(75.00)$ \\
\hline 12 & $\begin{array}{l}\text { Herbicides application (Pendimethalin 1day after } \\
\text { sowing) }\end{array}$ & $16(13.00)$ & 0.00 & 104(87.00) \\
\hline 13 & Plant protection measures (IPM) & $6(5.00)$ & $65(54.00)$ & $49(41.00)$ \\
\hline 14 & $\begin{array}{l}\text { Harvesting \& Threshing using small machines } \\
\text { (Tools and Small machines) }\end{array}$ & $98(82.00)$ & $10(8.00)$ & $12(10.00)$ \\
\hline & Total responses & 670 & 317 & 693 \\
\hline & Score (continuum) assigned & 3 & 2 & 1 \\
\hline & \% Application & 60.20 & 19.00 & 20.80 \\
\hline
\end{tabular}

*Applied more than the recommended (6 to $10 \mathrm{kgs} / \mathrm{ac}$ ) 
Table.5 Constraints in application of recommended good agricultural practices of Redgram cultivation as perceived by the respondents $(n=120)$

\begin{tabular}{|c|c|c|c|}
\hline Sl. No. & Constraints & $\mathbf{F}$ & $\%$ \\
\hline \multicolumn{4}{|c|}{ A. Input constraints } \\
\hline 1 & High wages \& timely non-availability labourers & 78 & 65.00 \\
\hline 2 & $\begin{array}{l}\begin{array}{l}\text { Lack of financial assistance in time from government during droughts } \\
\text { and floods. }\end{array}\end{array}$ & 72 & 60.00 \\
\hline 3 & $\begin{array}{l}\text { Non-availability of good quality of inputs timely at affordable price } \\
\text { in the market }\end{array}$ & 72 & 60.00 \\
\hline \multicolumn{4}{|c|}{ B. Management constraints } \\
\hline 4 & $\begin{array}{l}\text { Inadequate protective irrigation facility during critical sages of the } \\
\text { crop growth. }\end{array}$ & 65 & 54.16 \\
\hline 5 & $\begin{array}{l}\text { High incidence of pests and diseases \& its high management } \\
\text { (Chemicals). }\end{array}$ & 55 & 45.83 \\
\hline \multicolumn{4}{|c|}{ C. Technical constraints } \\
\hline 6 & $\begin{array}{l}\text { Lack of timely advisory services; technical guidance from the } \\
\text { developmental agencies right from seed to harvest. }\end{array}$ & 15 & 12.50 \\
\hline \multicolumn{4}{|c|}{ D. Marketing constraints } \\
\hline 7 & Market price fluctuation and low support price from Govt. & 95 & 79.16 \\
\hline 8 & Distant location of Market places to transport extra cost. & 69 & 57.50 \\
\hline 9 & Middlemen involvement at the market centres & 30 & 25.00 \\
\hline 10 & No ideal storage facility nearby places & 27 & 22.50 \\
\hline
\end{tabular}

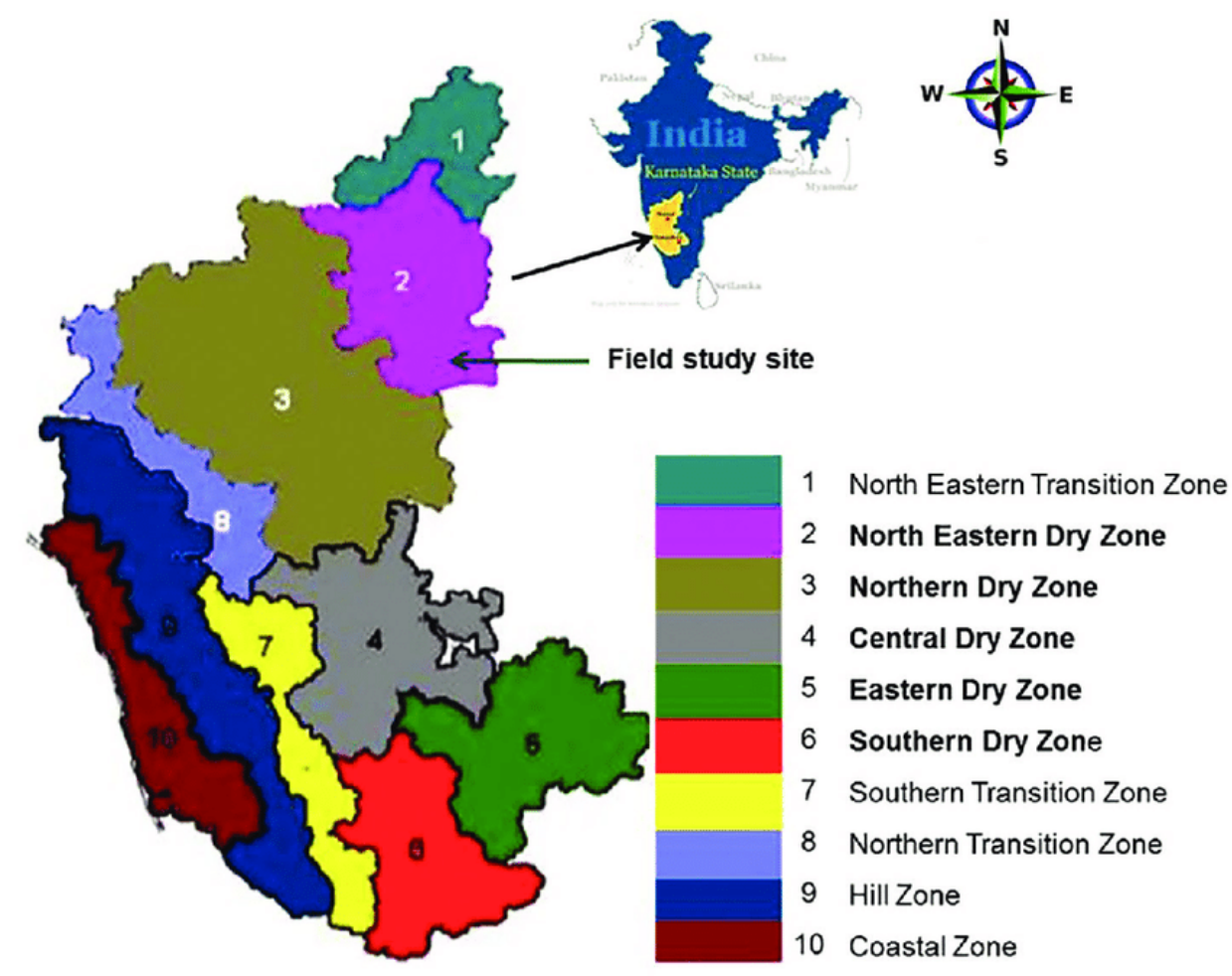

Source: Census India 2011

Figure.1 Research study area 


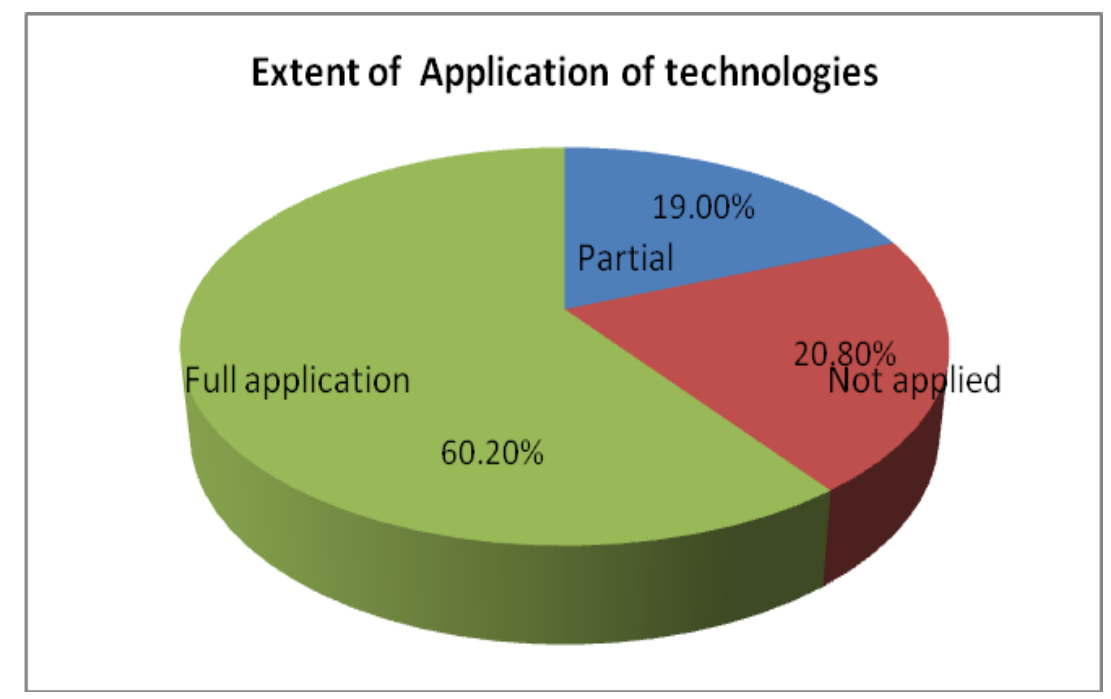

Figure.2 Extent of technological application, Redgram cultivation practices

To conclude, the study found that the Redgram growers had low social, psychological and economic profile, which inhibited them to apply the recommended technologies of farm universities. The extents of application was 60.20 percent. The perceived constraints of the growers were many among them, the most severe one was not getting remunerative price as the market price as there was high fluctuation market price coupled with, the support price announced by the Government was meager and not procuring all the quantity, secondly there was high labour wages and their scarcity to undertake the timely production operations, likewise the three other constraints were ranked.

Implications of the study being, effective of utilisation of scientific expertise from the nearby formal extension feeder institutes located at gross root level, such as Krishi Vigyan Kendras at gross root level for conducting regular off- campus training for the farmers. Organising Farmers' Field Schools at cluster village centres. Enabling the field staff to spend more time in advisory services from Raith Samparka Kendras. Formation of Farmer Produce Organisations and organising the extension programs through them would ensure better participation of growers in the extension activities and programs. Strengthening informal service providers, encouraging progressive farmers as parallel extension workers, inclusion of input and the private extension agencies in to the National extension main stream for diffusion of farm technologies go long way to reduce the gap in application of improved technologies.

\section{Acknowledgement}

I acknowledge the support given by esteemed University for the opportunity to guide the M.Sc student. I also thank the advisory committee members in guiding the students and completion of his M.Sc program successfully. Finally, I convey sincere gratitude to the farmers for giving their valuable information in compilation of data and findings.

\section{References}

Agripedia.com ICAR Portal, Indian Council of Agricultural Research, Government of India. 
FAO 2016. www.fao.org/pulsses-2016

Feaster, J.G, 1968, Measurement and determination of innovation among primitive agriculturists. Rur. Social., 33: 339-348.

GoK 2015, Government of Karntaka, Report on Area, Prodcution \& Productivity and prices of Agricultural crops in Karnataka, DES No.9:11.

Indiastat.com/agriculture-data/2/agriculturalproduction

Kerlinger, F. N., 1973, Foundations of Behavioural Research. Holt Rinehart and Winston Inc., New York.

Maraddi, G. N, 2006, An analysis of sustainable cultivation practices followed by Sugarcane growers in Karnataka. Ph.D. Thesis (Unpub.), Univ. Agric. Sci., Dharwad.

Package of practices 2010, Directorate of Extension, University of Agricultural Sciences Bangalore, Karnataka: 123131

Prakash, P., 2000, A study on the technological gap, grain yield gap and constraints of paddy cultivation in Palakkad district of Kerala. M. Sc. (Agri.) Thesis, Univ. Agric. Sci., Bangalore.

Rajashekar, 2009, An analysis of technological gap in papaya cultivation in Bidar and Gulbarga districts of North Karnataka. M. Sc (Agri.) Thesis, Univ. Agric. Sci.,
Dharwad.

Ranish, V. P., Malik, R. S. and Punia, R. K., 2001, Adoption of rapeseed - mustard production technology, Indian J. Extn. Edu., 37 (1\&2) : 58-62.

Ray, G. L., Chatterjee, P. and Banerjee, S. N., 1995, Technological Gap and Constraints in Agric. Tech. Tran., Naya Prakash, Calcutta, p. 27.

Saravanakumar, R, R., 1996, A Study on Management of Mango Gardens by Farmers in Krishnagiri Taluk of Dharmapuri District, Tamil Nadu. $M$. Sc. (Agri.) Thesis, (Unpub.), Univ. Agric. Sci., Dharwad. Karnataka.

Shashidhara, K. K., 2003, A study on socioeconomic profile of drip irrigation farmers in Shimoga and Davengere district of Karnataka. M. Sc (Agri.) Thesis, Univ. Agric. Sci., Dharwad, Karnataka

Supe, S.V., 1969, Factors related to different degrees of rationality in decision making among farmers. Ph. D Thesis (Unpub.), IARI, New Delhi.

UN report, 2017. State of Food Security and Nutrition in the World. www.wfp.org/publications/2017-statefood

Wondangbeni, K. 2010, Adoption Gap in Groundnut Production in Northern Transition Zone of Karnataka.

\section{How to cite this article:}

Mohd. Riyaz, D. Raghupathi and Venkatesh. M. 2020. Socio - Economic Psychological Profile of Redgram (Cajanus cajan L. Mill sp.) Growers and Perceived Constraints and Suggestions for Application of Production Technologies. Int.J.Curr.Microbiol.App.Sci. 9(03): 1540-1549. doi: https://doi.org/10.20546/ijcmas.2020.903.180 